\title{
The influence of factors of work environment and burnout syndrome on self-efficacy of medical staff
}

\author{
Iwona Nowakowska', Renata Rasińska', Maria Danuta Głowacka' \\ 1 Faculty of Health Sciences, Department of Organisation and Management, Karol Marcinkowski University of Medical \\ Sciences, Poznań, Poland
}

Nowakowska I, Rasińska R, Głowacka MD. The influence of factors of work environment and burnout syndrome on self-efficacy of medical staff. Ann Agric Environ Med. 2016; 23(2): 304-309. doi: 10.5604/12321966.1203895

\begin{abstract}
I Abstract
Introduction and objective. Conditions of a healthy, friendly and safe work environment and proper work organisation increase self-efficacy and decrease or eliminate the factors causing the occurrence of burnout symptoms, all of which have a decisive impact on increasing the quality of work. The aim of the study was to analyse and assess the influence of factors of work environment and burnout syndrome on the self-efficacy of medical staff.

Material and methods. The study comprised randomly selected professionally-active nurses working on hospital wards $(\mathrm{N}=405)$ on the area of two provinces in Poland. The study used the Generalized Self-Efficacy Scale, Copenhagen Burnout Inventory and a questionnaire concerning the factors that influence the process of work organisation at nursing positions in hospitals.

Results. Lower scores for self-efficacy resulted in a worse assessment of development opportunities and promotion prospects $(r=-0.11)$, participation in the decision-making process $(r=-0.11)$ and teamwork $(r=-0.10)$. Lower self-efficacy contributed to the occurrence of burnout symptoms $r \in[-0.19--0.17]$.

Conclusions. Properly shaped and used organisational factors are stimulating for professional efficiency and effectiveness, and consequently, for the quality of nursing work. Negative assessment of the factors in the work environment contributes to the occurrence of burnout symptoms and decrease in self-efficacy. Nurses with lower self-efficacy more often experienced symptoms of burnout.
\end{abstract}

\section{Key words}

work environment, work organisation, quality of work, medical staff, professional burnout syndrome, self-efficacy

\section{INTRODUCTION}

Hospitals belong to a group of non-profit organisations that provide medical services to the public. The quality of their services is an unquestionable indicator of prestige and the position of an institution in the environment. A necessary condition to achieve high quality services is to ensure the proper process of quality of work management in all members of the organisation. Attitudes of the employees, their commitment, professional efficiency and effectiveness depend on the actions of team members and the conditions in which they have to perform their duties on a professional basis.

Crucial for ensuring the proper process of quality management in task forces are properly implemented and skilfully used forms of counteracting unfavourable events leading to distortions in the work process. This applies to the sphere of work organisation with particular emphasis on factors that contribute to self-efficacy and prevention of stress and burnout. The role of managerial staff in healthcare facilities is the use of tools and methods that will reasonably protect employees and will help create a healthy and safe work environment. These measures will consequently provide optimal conditions for developing and maintaining the high

Address for correspondence: Iwona Nowakowska, Faculty of Health Sciences, Department of Organisation and Management, Karol Marcinkowski University of Medical Sciences, Smoluchowskiego 11, 60-179 Poznań, Poland

E-mail: iwona.nowakowska@poczta.onet.pl

Received: 13 December 2012; accepted: 26 January 2014 quality of work in task forces [1,2]. Creating a healthy and safe working environment is a necessary criterion for achieving satisfactory results in this field. Self-efficacy may be the link connecting the conditions of healthy work environment in the hospital and effectiveness of staff, which is a factor enabling the maintaining of individualism while, at the same time, effectively performing professional duties in a healthy and safe work environment.

According to Bandura [3], the level of self-efficacy is determined by the awareness of one's abilities to achieve the established goals and perform tasks in various areas of functioning. This can be determined by four levels:

1) building a strong sense of professionalism which, in turn, significantly affects the strengthening of belief in one's own potential;

2) observation and reaching for the experience of others, since seeing other people's successes through the prism of one's own abilities gives a sense of positive realisation of tasks leading to the aim pursued;

3) social persuasion, which involves a verbal message concerning the classification of possessed predispositions, capacity for action;

4) elimination of the tendency to pejorative interpretation of states, and the ability to reduce the individual's response to stressors.

Juczyński [4] defines self-efficacy as "a person’s belief about their chances of achieving the intended purpose in a particular situation". Effectiveness is inextricably linked 
with the control over one's own actions. People who present a high level of self-efficacy are able to reduce potential health problems more efficiently and achieve more noticeable results when they decide to change current behaviours that negatively affect health.

Experiencing a low level of self-efficacy may be caused by occupational stress, and is one of the main causes of decreased quality of work [5]. During task realisation, nurses often have a sense of professional functioning in the conditions of stress, which has its source in the work environment. A variety of these factors, their severity and personality traits influence the response of an organism. Over time, they can result in the occurrence of burnout symptoms. This phenomenon became a scientific subject of interest in the 1970s when in $1974 \mathrm{H}$. Freudenberger defined the burnout syndrome as: "a state of extreme exhaustion caused by excessive demand for energy and all the resources which an individual possesses" [6]. The current imbalance between the employee's possibilities and professional duties can lead to a state of overload $[7,8]$. The multidimensionality of this state was emphasised by two American scientists, Ch. Maslach and S. Jackson, who at the same time classified the three basic components: emotional exhaustion, depersonalisation and a reduced sense of personal accomplishments $[7,9,10]$.

Among the factors that contribute to burnout, and have their sources in both the organisational and individual sphere, the following causes have been highlighted:

- situational and organisational: low professional status, lack of a proper incentive system, lack of clearly defined job requirements and inadequate workload, limited career opportunities, as well as complex medical technologies;

- personal: low resistance to stress and a high level of selfcriticism, temperament, too high requirements concerning task realisation;

- interpersonal: disturbances in the communication process, lack of support and a low level of self-motivation [11].

The effort to define the process of burnout in Europe was taken by scientists from Copenhagen under the direction of Prof. Tage S. Kristensen. The Danish concept states that the main reasons for the emergence of burnout syndrome are fatigue and exhaustion, which may occur in every sphere of human activity [12]. The researchers identified three components characteristic for this state:

1) "Personal burnout is a state of prolonged physical and psychological exhaustion";

2) "Work burnout is a state of prolonged physical and psychological exhaustion, which is perceived as related to the person's work";

3) "Client burnout is a state of prolonged physical and psychological exhaustion, which is perceived as related to the person's work with clients" [13].

The involvement of the research team and the continuity of the work led to the development of the research tool, the Copenhagen Burnout Inventory (CBI) which, according to scientists, is the research instrument adapted to the European realities.

\section{MATERIAL AND METHODS}

The aim of the conducted studies was to analyse and assess the influence of factors of work environment and burnout syndrome on self-efficacy of medical staff.

The study involved 405 professionally active nurses working on hospital wards. Subjects from randomly selected wards filled-in an anonymous questionnaire. The necessary condition to participate in the studies was a declared consent. The study was conducted in the first quarter of 2010 in the area of two provinces of Poland.

The study was carried out by means of two standardised research tools and own questions concerning organisational factors in the work process in a hospital, as well as demographic questions. To evaluate nurses' self-efficacy, the Polish version of the Generalized Self-Efficacy Scale (GSES) by R. Schwarzer, M. Jerusalem and Z. Juczyński was used [4]. Burnout was assessed by means of the Copenhagen Burnout Inventory (CBI), developed by Tage S. Kristensen, along with a team of co-workers [12]. To assess the area of work organisation in a hospital environment, a set of questions was developed, taking into account the necessary elements of the work process. The last part of the questionnaire comprised a set of demographic questions.

The study was approved by the Bioethics Commission of the university (Permission Act: 1000/09-03.12.2009).

In order to analyse the empirical material, the computer programme STATISTICA 6.0 was used. Statistical tests were carried out at the significance level $\alpha=0.05$.

To analyse the results, the following statistical methods were used:

1. $\chi^{2}$ test for independence - to evaluate the dependence between immeasurable features $(\mathrm{x}, \mathrm{y})$ which are of a qualitative nature.

2. Spearman's rank correlation coefficient - a measure of the statistical dependence between two variables, measured on an ordinal scale to assess their direction.

3. Kruskal-Wallis test - extended with the bilateral comparisons test.

Aanalysis of the reliability of the measurement was performed using Cronbach's alpha test (alpha $=0.87$ ). The adaptation of the CBI was carried out with the participation of interpreters and members of the team, as well as multiple verification of the text to produce a final version corresponding with the original, a version which is intelligible and grammatically correct.

\section{RESULTS}

The study involved 405 professionally active nurses working on hospital wards. $42 \%$ of the respondents were aged $31-40$ years. Those aged over 51 and up to 25 constituted the least numerous group ( $4 \%$ and $6 \%$, respectively). Women aged 41-50 years constituted $38 \%$, and $10 \%$ of the nurses were $25-30$ years old. The average age was 38 . The majority (72\%) were married. $46 \%$ of the women had secondary education, $39 \%$ had completed studies at undergraduate level, and 15\% had a Master's Degree. Among the respondents, 32\% of the nurses had been employed for more than 21 years. $28 \%$ of the women were seniors - 16-20 years. For 19\%, the seniority was between 11-15 years. Those whose work experience was 
the shortest accounted for $13 \%$, and for $8 \%$ it was $6-10$ years. Among the respondents, $15 \%$ held managerial positions, the remainder worked in frontline positions. $74 \%$ of the examined nurses did shift work. More than half (58\%) of the respondents worked in surgical wards and the others in medical treatment wards. The most numerous group of the surveyed nurses were those employed in internal wards and accounted for every fifth respondent (20\%). The numbers of women employed in surgical and anesthesiology wards with an intensive care unit were, respectively, $15 \%$ and $12 \%$. Among the surveyed women, 9\% were cardiac nurses, $8 \%$ were employed in neurological and paediatric wards. Hospital emergency departments employed 7\%, oncological wards $6 \%$, and orthopedic - $5 \%$ of the nurses. The employment in other types of wards ranged from $4 \%-2 \%$, while the least numerous group worked in ophthalmological, ENT and psychiatric wards. The respondents lived in the Kuyavian and Pomeranian Voivodeship (50\%) and in the Wielkopolska Voivodeship (50\%).

Correlations for the demographic data were also examined using Spearman's coefficient. Apart from the obvious interdependencies (e.g., older people have more seniority: $r=0.86$ ) some statistically interesting relationships were fund; for example, it appears that in the examined group, the more seniority the respondents had, the more frequently they performed shift work $(r=0.29)$. It was also revealed that people with less seniority in total usually had a higher education $(r=-0.29)$, and more frequently occupied leadership positions $(r=-0.23)$. This fact can be explained by changes in the system of nurse education, which resulted in the elimination of secondary medical schools in favour of higher education at the undergraduate and graduate level.

Work organisation and professional burnout (including personal burnout, work-related and burnout in contact with patients). While analysing the obtained values of $r$ coefficients in the Spearman's rank correlation test (Tab. 1), it is worth noting that in all cases there were positive and statistically significant relationships between the factors that define work organisation and three types of burnout.

Table 1 shows that in the case of personal burnout the weakest link is noticeable for questions concerning intangible motivation to work $(r=0.09)$. The strongest relationship existed between this type of professional burnout and the financial motivation to work $(r=0.29)$. Dependencies of similar strength also existed for performing tasks in teams $(r=0.27)$, precision in determining the scope of responsibilities and professional role $(r=0.26)$, as well as work organisation $(r=0.24)$ and participation in the decision-making process $(r=0.23)$. The obtained results allow the conclusion that nurses affected by personal burnout symptoms evaluated the above factors occurring in the work process worse than the remainder classified in this area.

Among those who were burnt-out in consequence of the work performed, the strongest association was observed for participation of nurses in the decision-making process $(r=0.25)$, followed by work organisation $(r=0.24)$, performing tasks in teams $(r=0.23)$, tangible forms of motivating to work $(r=0.23)$, and precision in determining the scope of responsibilities and professional role $(r=0.22)$. This means that nurses who were burned-out in as a consequence of the work performed, evaluated these factors worse than the others. For the evaluation of intangible forms of motivation to work, the correlation with work-related burnout was the weakest $(r=0.13)$, which allows the conclusion that the respondents were the least critical of this particular factor (Tab. 1).

When analysing correlations obtained for burnout in contacts with patients, the weakest link existed between this type of burnout and the conditions associated with the equipment in the workplace $(r=0.13)$ and intangible forms of motivation to work $(r=0.14)$. Analysis of correlation coefficients showed that the strongest associations existed for tangible ways of motivating to work $(r=0.31)$ and participation in the decision-making process $(r=0.31)$, which reflects the greatest dissatisfaction with these two factors. A statistically significant association was also observed for performing tasks in teams $(r=0.27)$, opportunities for development and promotion $(r=0.27)$, number of staff on duty in relation to the needs $(r=0.26)$, as well as work organisation $(r=0.25)$ and precision in determining the scope of responsibilities and professional role $(r=0.24)$. The obtained results allow the conclusion that nurses who felt burnt out as a consequence of contacts with patients often spoke critically about the above factors, and consequently their negative assessment could, in a practical way, affect the quality of work process (Tab. 1).

Summarising the statistically significant correlations occurring between the area of work organisation and burnout, it should be noted that in each of the three types of burnout, two factors were evaluated most critically by the respondents, i.e. tangible forms of motivation to work

Table 1. Values of Spearman's rank correlation coefficients for factors of work environment and professional burnout syndrome (including personal burnout, work-related and burnout in contact with patients) as well as self-efficacy

\begin{tabular}{|c|c|c|c|c|}
\hline & Personal burnout & $\begin{array}{l}\text { Work-related } \\
\text { burnout }\end{array}$ & $\begin{array}{l}\text { Burnout in contact } \\
\text { with patients }\end{array}$ & Self-efficacy \\
\hline Performing tasks in teams & $0.27^{*}$ & $0.23^{*}$ & $0.27^{*}$ & $-0.10^{*}$ \\
\hline Work organisation & $0.24^{*}$ & $0.24^{*}$ & $0.25^{*}$ & -0.08 \\
\hline Number of staff on duty in relation to needs & $0.15^{*}$ & $0.21^{*}$ & $0.26^{*}$ & 0.03 \\
\hline Participation in the decision-making process & $0.23^{*}$ & $0.25^{*}$ & $0.31 *$ & $-0.11^{*}$ \\
\hline Intangible forms of motivating to work & $0.09^{*}$ & $0.13^{*}$ & $0.14^{*}$ & 0.01 \\
\hline Tangible forms of motivating to work & $0.29 *$ & $0.23^{*}$ & $0.31^{*}$ & -0.09 \\
\hline Salary & $0.19^{*}$ & $0.16^{*}$ & $0.18^{*}$ & -0.04 \\
\hline Precision in determining the scope of responsibilities and professional role & $0.26^{*}$ & $0.22^{*}$ & $0.24^{*}$ & $-0.07^{*}$ \\
\hline
\end{tabular}


$r \in[0.23-0.31]$, and participation of nurses in the decisionmaking process $r \in[0.23-0.31]$. The respondents also strictly assessed performing tasks in teams $r \in[0.23-0.27]$. It is also worth emphasizing that, together with the evaluation of the areas of burnout, an increasing dissatisfaction was observed among the respondents with the opportunities for development and promotion $r \in$ [0.17-0.27], work organisation, $r \in[0.24-0.25]$, and the number of staff on duty in relation to needs $r \in[0.15-0.26]$. It was also noticed that only for one factor - conditions associated with equipment in the workplace, dissatisfaction with this aspect was lower among the women burnt-out through contact with patients $(r=0.13)$, than among others who were burnt-out, where the value was $r=0.20$ (Tab. 1 ).

Self-efficacy of Polish nurses and work organisation. Among the nurses participating in the survey as many as $60 \%$ highly evaluated their self-efficacy, while $36 \%$ evaluated it as average. Only $4 \%$ of the respondents provided answers which confirmed their low self-efficacy.

During the analysis of the Spearman's rank correlation coefficients, the presence was observed of a statistically significant relationship between the generalised self-efficacy and socio-demographic data of the respondents. The strongest negative correlation existed for the generalised self-efficacy of nurses and work in a managerial / frontline position $(r=-0.15)$. This means that the respondents who occupied frontline positions assessed their effectiveness as being worse. Other positive correlations concerned such variables as age $(r=0.12)$, marital status $(r=0.11)$ and shift work $(r=0.11)$. This allowed the conclusion that the older nurses who were married and worked in shifts evaluated their effectiveness higher.

Based on the Generalized Self-Efficacy Scale, an attempt was made to assess the effectiveness of nurses and mutual relationships with the area of work organisation. Subsequently, correlations of these areas with personal burnout, workrelated, and burnout in contact with patients were analysed.

During the analysis of values of the Spearman's rank correlation coefficients (Tab. 1), the existence of statistically significant relationships between self-efficacy of nurses and the areas belonging to work organisation was observed. These links involved performing tasks in teams $(r=-0.10)$, opportunities for development and promotion prospects $(r=-0.11)$, as well as participation in the decision-making process $(r=-0.11)$. This means that nurses with a lower level of self-efficacy more negatively evaluated the teamwork in their organisation, participation in the decision-making process, as well as opportunities for development and promotion prospects.

Nurses' self-efficacy and burnout. When analysing nurses' self-efficacy, the relationship between this area and professional burnout (including the three types of burnout) was measured. On this basis, the results of $\chi^{2}$ test for independence, Kruskal-Wallis test and Spearman's rank correlation test were obtained (Tab. 2).

Based on Table 2, the presence of statistically significant relationships for the level of respondents' self-efficacy and three types of burnout was observed. Confirmation of this finding are the obtained values of coefficients in $\chi^{2}$ test for independence.

Values of the Kruskal-Wallis test (Tab. 2) confirmed this theory and provided information about the existence of
Table 2. P-values of $X^{2}$ test for independence, $p$ in the Kruskal-Wallis test, and $\rho$ in the Spearman's rank correlation test for generalised self-efficacy of nurses and burnout (including personal burnout, work-related and in contact with patients)

\begin{tabular}{lccc}
\hline & $\begin{array}{c}x^{2} \text { test for } \\
\text { independence }\end{array}$ & $\begin{array}{c}\text { Kruskal- } \\
\text { Wallis test }\end{array}$ & $\begin{array}{c}\text { Spearman's } \\
\text { rank } \\
\text { correlation test }\end{array}$ \\
\hline Personal burnout & $0.00070^{*}$ & $0.0001^{*}$ & $-0.19^{*}$ \\
\hline Burnout work-related & $0.00025^{*}$ & $0.0002^{*}$ & $-0.19^{*}$ \\
\hline Burnout in contact with patients & $0.00074^{*}$ & $0.0008^{*}$ & $-0.17^{*}$ \\
\hline
\end{tabular}

* cases statistically significant at significance level of $\alpha=0.05$

differences between the highlighted conditions in each of the types of burnout (lack of burnout, risk of burnout, presence of burnout). These differences occurred:

- in the case of personal burnout $(\mathrm{p}=0.0001)$ - nurses without symptoms of burnout vs. nurses personally burnt- out ( $p$-value in the test of bilateral comparisons $-p=0.0001$ );

- in the case of work-related burnout ( $\mathrm{p}=0.0002)$ : - nurses without symptoms of burnout vs. nurses burnt-out in connection with work ( $p$-value in the test of bilateral comparisons $-\mathrm{p}=0.0002)$;

- in the case of burnout in contact with patients ( $\mathrm{p}=0.0008)$ : - nurses without symptoms of burnout vs. nurses burntout in contact with patients ( $\mathrm{p}$-value in the test of bilateral comparisons is $\mathrm{p}=0.0061$ ); - nurses at risk of burnout through contact with patients vs. nurses burnt-out in this area ( $p$-value in the test of bilateral comparisons is $\mathrm{p}=0.0055)$.

Analysis of $\rho$-values for the Spearman's rank correlation test (Tab. 2) showed that in all the examined areas statistically significant, negative correlations were obtained, and the strongest existed between nurses' self-efficacy and personal burnout $(r=-0.19)$ and work-related burnout $(r=-0.19)$, suggesting that nurses with a lower level of self-efficacy more often experienced symptoms of burnout. It should be noted, however, that they more often experienced the symptoms of personal and work-related burnout, rather than burnout through contact with patients $(r=-0.17)$.

\section{DISCUSSION}

When analysing the literature and empirical research results, a frequently raised fact is that personality traits and demographic factors are secondary causes of the burnout syndrome. The most dangerous are those are directly connected with the work environment, both physical factors, as well as psychosocial factors in the work environment [14, Cf:15]. A Danish researcher, M. Borritz [16] noticed that the greatest impact on the occurrence of personal burnout symptoms was made by the following factors: excessive workload and emotional demands, role conflicts, lack of or limited opportunities for professional development, and lack of precision in formulating a professional role. While classifying the determinants affecting work-related burnout, in addition to the above-mentioned, there also appears too fast a pace of work. Burnout in contact with patients is caused, according to the author of the research, by emotional factors such as hiding one's feelings and searching for answers to questions connected with the meaning of work, which leads 
to a significant emotional burden. Apart from the abovementioned factors, also worth noticing are role conflicts and lack of precision in defining the professional role [16]. Similar results were obtained in the studies conducted by Duquette and co-workers [17]. They showed that a role conflict, time pressure, lack of job satisfaction and too strong emotional involvement were the strongest correlates of burnout among nurses. Research by Kristensen and by Hasselhorn with their teams $[12,18]$ led to similar conclusions. A strong emotional commitment was the cause of burnout among nurses employed in medical institutions of North Carolina, USA [19]. Subsequent research confirmed that burnout is associated with emotional exhaustion, cynicism and low efficiency [20].

According to Perek et al. [21], difficult situations occurring in the professional life of nurses are influenced by organisational and physical working conditions. The research conducted by J. M. Sadovich [22] led to the conclusion that a high level of job satisfaction and positive perception of the factors affecting nurses' work process reduces burnout syndrome. Japanese nurses recognised as the main causes of burnout: excessive workload, poor physical conditions in the work environment and an inadequate education system, as well as no or little participation in the decision-making process [23]. The need and awareness of professional development is associated with the increase in the level of self-efficacy and quality of work among nursing teams $[24,25]$. This is confirmed by the studies carried out by Tomaszewska et al. who showed that those areas were the most frequent. Among them, the quality of work, professional burnout, and raising the occupational prestige were mentioned. Nurses taking part in the study also noticed the mutual relationship between raising the qualifications (including self-study) and satisfaction with their own development $[26,27]$ and increased self-esteem [28].

It was also proved that the lack of performing tasks in teams and cooperation between professional groups is destructive to the quality of work and professional effectiveness [21, 29]. Other destructive factors are improper work organisation [30, $31,32]$ and bad conditions in terms of workplace equipment [32]. Dissatisfaction with professional effectiveness is also noticed by Polish nurses who have experienced the symptoms of burnout syndrome [1].

An alarming problem among nursing teams is the low level of job satisfaction which, in consequence, can lead to the occurrence of symptoms related to health $[33,34,35]$. Among the causes of this condition are often mentioned the lack of intangible motivation [36] and low salary [21, $33,37]$. These two factors influence the attitude of nurses to raising their qualifications, because they often indicate the lack of motivators and the financial aspect as some of the decisive obstacles in this area [26]. There was also a relationship between job satisfaction and organisational climate [37, Cf:38] and the level of quality of nurses' working life [39]. It was shown that formulating too high quantitative demands at work, combined with the lack of precision in defining the professional role, as well as few opportunities for professional development, contribute to the occurrence of burnout $[10,16,33]$.

The authors have proved that nurses often do not have a sufficient level of knowledge about their contemporary professional role [29]. An insufficient number of staff on duty in relation to needs is another factor revealed in the research, which is important for proper functioning in the workplace $[33,40,41,42]$. Thisv has been confirmed by the research of Piecewicz-Szczęsna [44]. The author points to the need for the practical use of standardisation of work, depending on the current needs of an institution [43] and rational use of the available working time of nurses [30], the more so because the characteristic feature of nursing working positions is their high "complexity" [44].

A crucial fact for the efficiency and effectiveness of teams, which has been confirmed by research results, is their integrity, competence and the atmosphere of mutual trust. Only such teams are able to develop a high quality of work on the organisational basis and contribute to greater efficiency in the workplace [45]. Unquestionable support for these activities is raising the professional prestige, appropriate determining of career paths and increasing the opportunities for professional development, as well as improving working conditions and salaries of nurses [46]. As demonstrated in the studies carried out by Hasselhorn et al. [18], the effort includes quantitative and emotional demands, and the gratuities may consist of recognition and respect, as well as the possibility of professional development, promotion and the level of salary.

Nurses who stated lower levels of self-efficacy claimed that the most common causes for this state are insufficient number of staff $[5,47]$ and the attitude of colleagues who do not perform their duties which, consequently, leads to an excessive workload on the others. These factors result in the experience of occupational stress which leads to reduction in the quality of work [5].

\section{CONCLUSIONS}

This study provides empirical evidence of the existence of the key influence of organisational factors in the work process, and the occurrence and intensification of burnout on the self-efficacy of professionally active nurses. The following factors affect the quality of work of nursing staff:

1) Properly shaped and used factors of the work environment stimulate professional efficiency and effectiveness, and the quality of medical staff.

2) Negative assessment of factors in the work environment contributes to the occurrence of burnout symptoms.

3) Symptoms of burnout are more often experienced by nurses with lower self-efficacy.

\section{REFERENCES}

1. Głowacka MD, Nowakowska I. Wypalenie zawodowe jako czynnik zmieniający efektywność pracownika. [In:] Głowacka, M.D, Mojs, E. (ed.) Profesjonalne zarządzanie kadrami w zakładach opieki zdrowotnej. Wyd. Wolters Kluwer Polska, Warszawa 2010 (in Polish).

2. Nowakowska I, Głowacka MD. Risk of Professional Burnout in the Work Process and Its Influence on the Professional Effectivenss of Nurses. [In:] Bizon-Górecka J. (ed.) Strategie zarządzania ryzykiem w przedsiębiorstwie - ryzyko przedsiębiorstwa a ryzyko projektu. Wyd. TNOiK, Bydgoszcz 2008 (in Polish).

3. Bandura A. Self-Efficacy. [In:] Ramachaudran V.S. (Ed.) Encyclopedia Human Behavior, Academic Press, New York, 1994; 4: 71-81.

4. Juczyński Z. Narzędzia pomiaru w promocji i psychologii zdrowia. Pracownia Testów Psychologicznych, Warszawa 2009 (in Polish).

5. Martens ML. (2009) A Comparison of Stress Factors in Home and Inpatient Hospice Nurses. J Hosp Palliat Nurs. 2009; 11(3): 144-153. 6. Freudenberger HJ. Staff Burnout. J Soc Issues.1974; 30(1): 159-165. 
7. Maslach C. Wypalenie - w perspektywie wielowymiarowej. [In:] Sęk H. (ed.) Wypalenie zawodowe. Przyczyny i zapobieganie. Wydawnictwo Naukowe PWN, Warszawa 2006 (in Polish).

8. Maslach C, Leiter MP. Prawda o wypaleniu zawodowym. Wydawnictwo Naukowe PWN, Warszawa 2011 (in Polish).

9. Maslach C, Jackson S. The Measurement of Experienced Burnout J Occup Behav. 1981; 2: 99-113.

10. Maslach C, Schaufeli WB, Leiter MP. Job Burnout. Annu Rev Psychol. 2001; 52: 397-422.

11. Mojs E, Głowacka MD. Wypalenie zawodowe u polskich pielęgniarek. Now Lek. 2005; 74, 2: 238-243 (in Polish).

12. Kristensen TS, Borritz M, Villadsen E, Christensen KB. The Copenhagen Burnout Inventory: A New Tool for the Assessment of Burnout. Work \& Stress, 2005; 19(3): 192-207.

13. Kristensen TS, Borritz M. Copenhagen Burnout Inventory, www.ami. dk/upload/udgivelser/cbi_data_uk.pdf (access: 02.09.2006).

14. Oandasan I, Baker G.R, Baker K, Bosco C, D'Amour D, Jones L, et al. Teamwork in Healthcare: Promoting Effective Teamwork in Healthcare in Canada. Canadian Health Services Research Foundation, Canada 2006.

15. Toscano P, Ponterdolph M. The Personality to Buffer Burnout. J Nurs Manag. 1998; 29(8): 32L-32R.

16. Borritz M. Burnout In Human Service Work - Causes and Consequences. PhD Thesis, www.ami.dk./upload/MB-phd.pdf (access: 26.09.2006).

17. Duquette A, Sandhu K, Beaudet L. Factors Related to Nursing Burnout: A Review of Empirical Knowledge. Issues in Mental Health Nurs. 1994; 15: 337-358.

18. Hasselhorn H-M, Tackenberg P, Peter R. Effort - Reward Imbalance among Nurses in Stable Countries and in Countries in Transition. Int J Occup Environ Health. 2004; 10(4): 401-408.

19. Meltzer LS, Missak Huckabay L. Critical Care Nurses Perceptions of Futile Care and Its Effect on Burnout. Am J Critic Care. 2004; 13(3): 202-208.

20. Hallsten L. Josephson M, Torgen M. Performance - Based Self-Esteem: A Driving Force in Burnout Processes and Its Assessment. National Institute for Working Life, Stockholm, Sweden 2005.

21. Perek M, Kózka M, Twarduś K. Trudne sytuacje w pracy pielęgniarek pediatrycznych i sposoby radzenia sobie z nimi. Problemy Pielęgniarstwa. 2007; 15(4): 223-228 (in Polish).

22. Sadovich JM. Work Excitement in Nursing: An Examination of the Relationship Between Work Excitement and Burnout. Nurs Econ. 2005; 23(2): 91-96.

23. Kishi R, Kitahara T, Masuchi A, Kasai S. Work - related Reproductive, Musculoskeletal and Mental Disorders among Working Women History, Current Issues and Future Research Directions. Industrial Health. 2002; 40: 101-112.

24. Bidzińska E, Sobczak M.D, Rakowska K.A. Motywy podwyższania wykształcenia przez pielęgniarki Wojewódzkiego Szpitala Zespolonego w Elblagu. Probl Pielęg. 2007; 15(2, 3): 197-202 (in Polish).

25. Dobrowolska B, Putowski M, Wrońska I, Kozak D, Cuber M. Zapotrzebowanie pielęgniarek I lekarzy na kształcenie podyplomowe z zakresu opieki nad pacjentem umierającym. Probl Pielęg. 2008; 16(1, 2): 48-53 (in Polish).

26. Cisoń-Apanasewicz U, Gaweł G, Ogonowska D, Potok H. Opinie pielęgniarek na temat kształcenia podyplomowego. Probl Pielęg. 2008; 17(1): 32-37 (in Polish).
27. Tomaszewska M, Cieśla D, Czerniak J, Dykowska G. Możliwość doskonalenia zawodowego pielegniarek - potrzeby a rzeczywistość. Probl Pielęg. 2008; 16(1,2): 40-47 (in Polish).

28. Dębska G, Cepuch G. Wypalenie zawodowe u pielęgniarek pracujących w zakładach podstawowej opieki zdrowotnej. Probl Pielęg. 2008; 16(3): 273-279 (in Polish).

29. Glińska J, Lewandowska M. Autonomiczność zawodu pielęgniarskiego $\mathrm{w}$ świadomości pielęgniarek $\mathrm{z}$ uwzględnieniem pełnionych funkcji zawodowych. Probl Pieleg. 2007; 15(4): 249-253 (in Polish).

30. Piecewicz-Szczęsna H, Matwiejczyk T, Walczuk E. Efektywność wykorzystania zasobów pielęgniarskich w lecznictwie stacjonarnym na Białorusi. Probl Pielęg. 2009; 17(4): 294-300 (in Polish).

31. Spence Laschinger H.K. Building Healthy Workplaces: Time to Act on the Evidence. Healthcare Papers. 2007; 7(Sp): 42-45.

32. Sternal D. Wprowadzanie zmian w organizacji opieki pielęgniarskiej w szpitalu na przykładzie programu profilaktyki odleżyn. Probl Pielęg. 2008; 16(1,2): 9-15 (in Polish).

33. Khani A, Jaafarpour M, Dyrekvandmogadan A. Quality of Nursing Work Life. J Clin Diagn Res. 2008; 2: 1169-1174.

34. Muthusamy E. Job Satisfaction: A Study Among Hospital Nurses in Coimbatore, India. Social Science Research Network, 2009: http://ssrn. com/abstract=1428444 (access: 28.12 .2009 ).

35. Płotka A, Pitek A, Makara-Studzińska M. Zespół wypalenia w zawodzie pielęgniarki. Probl Pielęg. 2001; 1-2: 221-232 (in Polish).

36. Kunecka D, Kamińska M, Karakiewicz B. Analiza czynników wpływających na zadowolenie $\mathrm{z}$ wykonywanej pracy $\mathrm{w}$ grupie pielęgniarek. Badania wstępne. Probl Pielęg. 2007; 15(2, 3): 192-196 (in Polish).

37. Murrells T, Robinson S, Griffiths P. (2008) Job Satisfaction Trends During Nurses' Early Career. BMC Nursing. 2008; 7(7): 1-9.

38. Matthews S, MacDonald-Rencz S. Health Workplaces and Teamwork for Healthcare Workers Need Public Engagement. Healthcare Papers. 2007; 7(Sp): 52-57.

39. Brooks BA, Storfiell J, Omoike O, Ohlson S, Stemler I, Shaver J et al. Assessing the Quality of Nursing Work Life. Nurs Adm Q. 2007; 31(2): $152-157$.

40. Kalisch BJ, Kyung H.L. Nurse Staffing Levels and Teamwork: A CrossSectional Study of Patient Care Units in Acute Care Hospitals. J Nurs Scholarsh. 2011; 43(1): 82-88.

41. Kennedy BR. Stress and Burnout of Nursing Staff Working With Geriatric Clients In Long-Term Care. J Nurs Scholarsh. 2005; 37(4): 381-382.

42. Shaver K, Lacey L. Job and Career Satisfaction among Staff Nurses. JONA. 2003; 33(3): 166-172.

43. Piecewicz-Szczęsna H. Normowanie pracy pielęgniarek a zapotrzebowanie na opiekę pielęgniarską w lecznictwie stacjonarnym na Białorusi. Probl Pielęg. 2008; 16(1,2): 1-8 (in Polish).

44. Tummers GER, Landeweerd JA, van Morode GG. Work Organisation, Work Characteristics and Their Psychological Effects on Nurses in the Netherlands. Int J Stress Manag. 2002; 9(3): 183-206.

45. Clements D, Dault M, Priest A. Effective Teamwork in Healthcare: Research and Reality. Healthcare Papers. 2007; 7(Sp): 26-35.

46. Wójcik G, Sienkiewicz Z, Wrońska I. Migracja zawodowa personelu pielęgniarskiego jako nowe wyzwanie dla systemów ochrony zdrowia. Probl Pielęg. 2007; 16(2,3): 120-127 (in Polish).

47. O'Reilly Ph. Barriers to Effective Clinical Decision Making in Nursing. www.ciap.health.nsv.gov.au/hospolic/stvincents/1993/a04html (access: 28.12.2009). 